\title{
ПОЛЯРИЗАЦИЯ И СЖАТИЕ ОСВОЕННЫХ ПРОСТРАНСТВ В ЦЕНТРЕ РОССИИ: ТРЕНДЫ, ПРОБЛЕМЫ, ВОЗМОЖНЫЕ РЕШЕНИЯ
}

\author{
ТАТЬЯНА НЕФЁДОВА, АНДРЕЙ ТРЕЙВИШ
}

\begin{abstract}
Поляризация и сжатие обжитых и освоенных территорий как следствие их крайне неравномерного развития стали одной из ключевых проблем не только всей России и её макрорайонов, но и отдельных регионов или их групп. Анализ одной из них, расположенной в историческом ядре страны вокруг Москвы, выявил резкие и нарастающие контрасты типа центр-периферия, вообще наиболее характерные для России. Их факторами стали специфика урбанизации, подверженной кризисным колебаниям, цุентростремительные миграции населения, депопуляциия внутренней периферии, особенно сельской, в условиях постсоветской пространственной перестройки экономики и расселения. Эти проиессы болезненны для обоих полюсов, центрального и периферийного, но на втором вызваннье ими проблемы стоят и ощущаются острее. Отношение к ним у населения, экспертов и чиновников различно. Выделень четыре основных возможных подхода к этим проблемам и варианта соответствующей политики и решений: 1) невмешательство в духе laissez-faire с надеждой на естественную смену (разворот) тренда сжатия; 2) ускорение сжатия в целях экономии бюджетных средств путём укрупнения поселений и социальных объектов; 3) его сдерживание, смягчение негативных социальных последствий доступными мерами; 4) поиск и всемерная поддержка новых, возвратных волн освоения (своего рода реконкисты) пустеющей периферии, среди которых в качестве одной из самых реальных, массовых и притом наименее затратных для государства выделяется дачная волна. У каждого варианта есть свои позитивнье и негативные, сильные и слабые стороны, бегльий обзор которых содержится в статье. Но выбор того или иного пути остаётся, как обычно, за политиками и управленцами.
\end{abstract}

Ключевые слова: пространство, центр, периферия, освоение, поляризация, сжатие, урбанизация, депопуляция, пространственная мобильность населения, дача (второй дом).

\section{ВВЕДЕНИЕ}

Говоря о пространственном развитии, у нас почти сразу переходят к освоению северных и восточных районов. Недавно это показало обсуждение Стратегии такого развития до 2025 г. на телеканале «Россия - Культура» в программе «Что делать?», где речь шла о Севере и Севморпути, Сибири и Дальнем Востоке, геополитических задачах страны, новых городах и дорогах ${ }^{1}$. Сказался советский и досоветский «ура-освоенческий» стереотип. Для него в России ещё хватает амбиции, но мало амуниции в виде мобильных ресурсов, особенно человеческих.

ТАТЬЯНА ГРИГОРЬЕВНА НЕФЁДОВА (trene12@igras.ru), ИНСТИТУТ ГЕОГРАФИИ РОССИЙСКОЙ АКАДЕМИИ НАУК, Россия.

АНДРЕЙ ИЛЬИч ТРЕЙВИШ (trene12@yandex.ru), ИНСТИТУТ ГЕОГРАФИИ РОССИЙСКОЙ АКАДЕМИИ НАУК, РОССИя.

РАБОТА ВЫПОЛНЕНА В РАМКАХ ПРОЕКТА РОССИЙСКОГО НАУЧНОГО ФОНДА №19-17-ОО174 ИНСТИТУТА ГЕОГРАФИИ РАН «РАЗВИТИЕ РАЙОНОВ СТАРОГО ОСВОЕНИЯ В УСЛОВИЯХ СОЦИАЛЬНО-ЭКОНОМИЧЕСКОЙ ПОЛЯРИЗАЦИИ И СЖАТИЯ ОСВОЕННОГО ПРОСТРАНСТВА ЕВРОПЕЙСКОЙ РОССИИ».

СТАТЬЯ ПОСТУПИЛА В РЕДАКЦИЮ В МАРТЕ 2020 Г.

1 Велика Россия... А где жить? (2020). Россия - Культура, 1 апреля. URL: https://tvkultura.ru/video/show/brand_id/20917/episode_id/1910574/video_id/1978978/ 
Ведущий программы В.Т. Третьяков риторически задал тему так: «Велика Россия... А где жить?», исходя из того, что наши гигантские пространства всегда были заселены неравномерно, а теперь это стало национальной проблемой. Стратегию ругали, среди прочего, за отрыв от человека с его повседневной жизнью. В ней к основным проблемам пространственного развития отнесены растущая демографическая нагрузка на трудоспособное население в большинстве субъектов РФ, угроза ухудшения ситуации из-за снижения рождаемости и уменьшения миграционного притока из стран ближнего зарубежья, внутрирегиональные различия по уровню развития, отставание уровня жизни на сельских территориях, низкая комфортность самой городской среды, в том числе в крупных городских агломерация ${ }^{2}$. Так что геодемографические и социогеографические вопросы из неё отнюдь не выпали.

В каких географических рамках изучать жизнь людей? Видимо, в разных, начиная с рамок обжитой и освоенной зоны. Она сжимается, занимая примерно треть территории России, но вмещая львиную и растущую долю её постоянного населения. При этом социальные контрасты велики и внутри российской ойкумены, отдельных регионов, их небольших групп. Данная статья посвящена одной группе, расположенной в ядре страны вокруг её столицы. Но сначала уточним соотношение неравномерности, концентрации, поляризации, сжатия - процессов, о которых идёт речь. По нашему мнению, это понятия одного ряда, но со своими нюансами, вкратце описанными ниже.

Неравномерность тесно связана с развитием, всегда неравномерным во времени и пространстве. На определенных этапах она может стимулировать развитие или затруднять его. Этой сложной и ёмкой теме посвящено море литературы, включая инновацнонную модель Эверетта Роджерса и гипотезу Артура Оукена об обратной связи равенства и эффективности (Rogers 1962; Okun 1975). Но они уводят глубоко в дебри общественнонаучной мысли.

Проще с концентрацией - сосредоточением некого явления в некой области, в том числе в пространстве. Пока развиваются и эти области (центры, очаги концентрации), и другие (периферийные), пусть разными темпами, это просто концентрация

При поляризащии (присущей как отдельным явлениям, так и всему пространству) где-то налицо рост, а где-то - убыль, упадок. Формируются два полюса; по крайней мере, так обычно считают регионалисты, иногда называя примерно то же самое сегрегацией, расслоением пространства.

При сжатии пассивный полюс-лузер тает, поскольку всё и вся тянется куда-то в центр: «в Москву, в Москву, в Москву» вслед за чеховскими сестрами. Отсюда недалеко до фрагментации пространства, его дробления на очаги жизни и выпадающие из неё провалы.

\footnotetext{
2 Распоряжение Правительства РФ от 13 февраля 2019 г. №207-р (ред. от 31.08.2019) «Об утверждении Стратегии пространственного развития Российской Федерации на период до 2025 года». КонсультантПлюс. URL: http://www.consultant.ru/document/cons_doc_LAW_318094/3a44f95591daeef4f5ec80bd79f99bd8197196ed/
} 
Впрочем, есть два типа сжатия социального геопространства, разные по сути и коннотации (Трейвиш 2010). Позволим себе о них напомнить.

Первое сжатие, коммуникационное (рисунок 1), скорее виртуальное, чем реальное, и воспринимаемое позитивно, означает рост доступности мест за счет коммуникаций. Питер Хаггет (1979: 382) назвал его имплозией, внутренним взрывом, когда большие «массы» типа крупных центров условно слипаются благодаря новым средствам сообщения, а вот «мелочь» до поры как бы разлетается от них и друг от друга, хотя физически все остаются на своих местах.

Второе сжатие, локационное, физически нагляднее, а отношение к нему чаще всего негативное, поскольку оно чревато потерей обжитых, освоенных, экономически активных земель (рисунок 1). Ниже в статье рассматривается в основном сжатие второго рода с учётом первого. Они вообще-то действуют вместе, обычно в пользу центров и против периферии, усиливая поляризацию и нередко фрагментацию пространства.
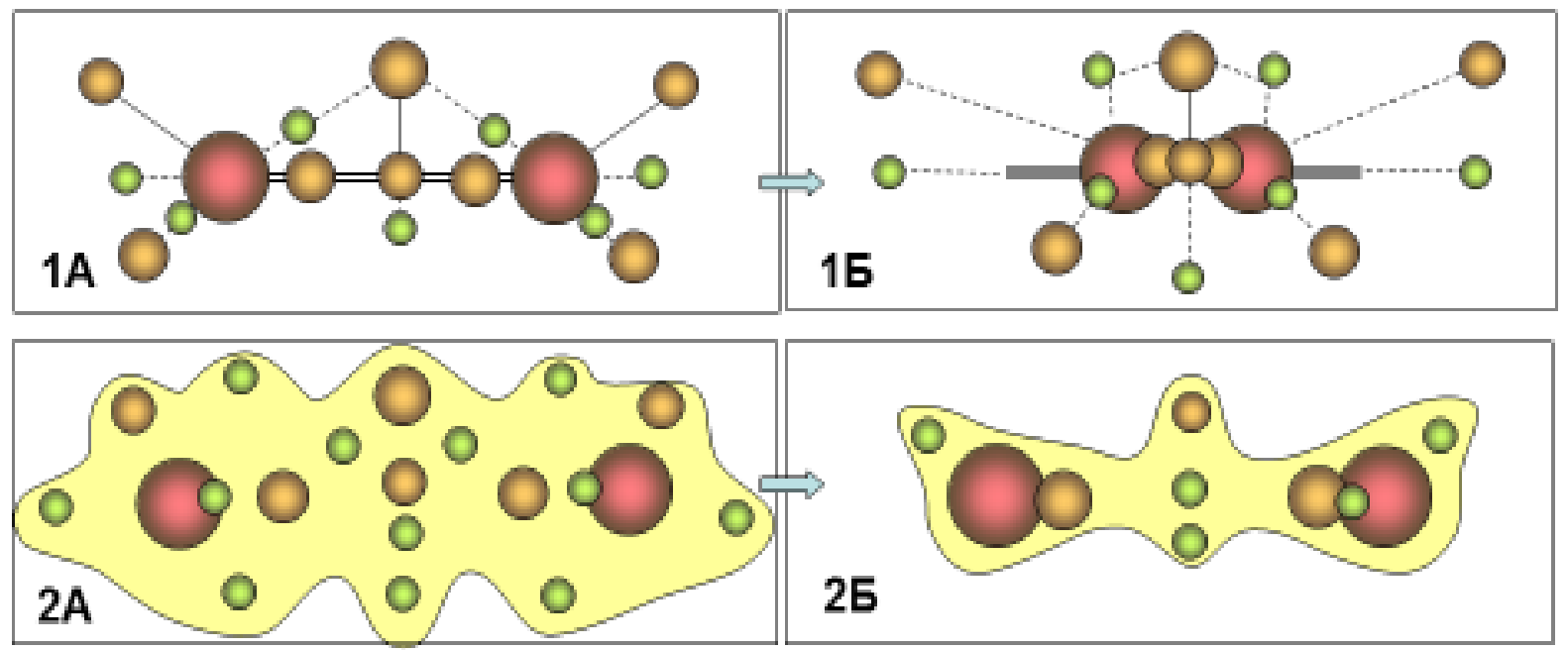

Рисунок 1. Два типа (трактовки) сжатия социального пространства. Условная схема 1А-1Б - коммуникационное, 2А-2Б - локационное (пояснения в тексте)

Источник: Построения авторов.

За всем этим стоит как минимум ещё один универсальный и междисциплинарный по научному ведению процесс - урбанизация. И всем им тесно в рамках какой-то одной науки, ведь в жизни явления разной природы переплетаются. Демографический контекст так или иначе присутствует или выходит на первый план. Отдельные разделы статьи касаются урбанизации, миграций и занятости, сельской депопуляции. В конце сформулированы вопросы для обсуждения и варианты решения выявленных проблем. 


\section{ВОЛНЫ УРБАНИЗАЦИИ В РОССИИ И ЕЁ ЦЕНТРЕ}

Избранный нами центральный ареал включает Москву, Московскую область (вместе это Московский столичный регион, МСР) и 9 окружающих областейํ․ По площади он сравним с Германией, Польшей, Финляндией, хотя Германия далеко впереди по демоэкономическим масштабам (рисунок 2). Наш ареал в полном составе по площади ближе к Польше, а если убрать МСР, то к Финляндии, но там обширные пространства, особенно северные, похожи не столько на Центр России, сколько на её Север или Северо-Запад.

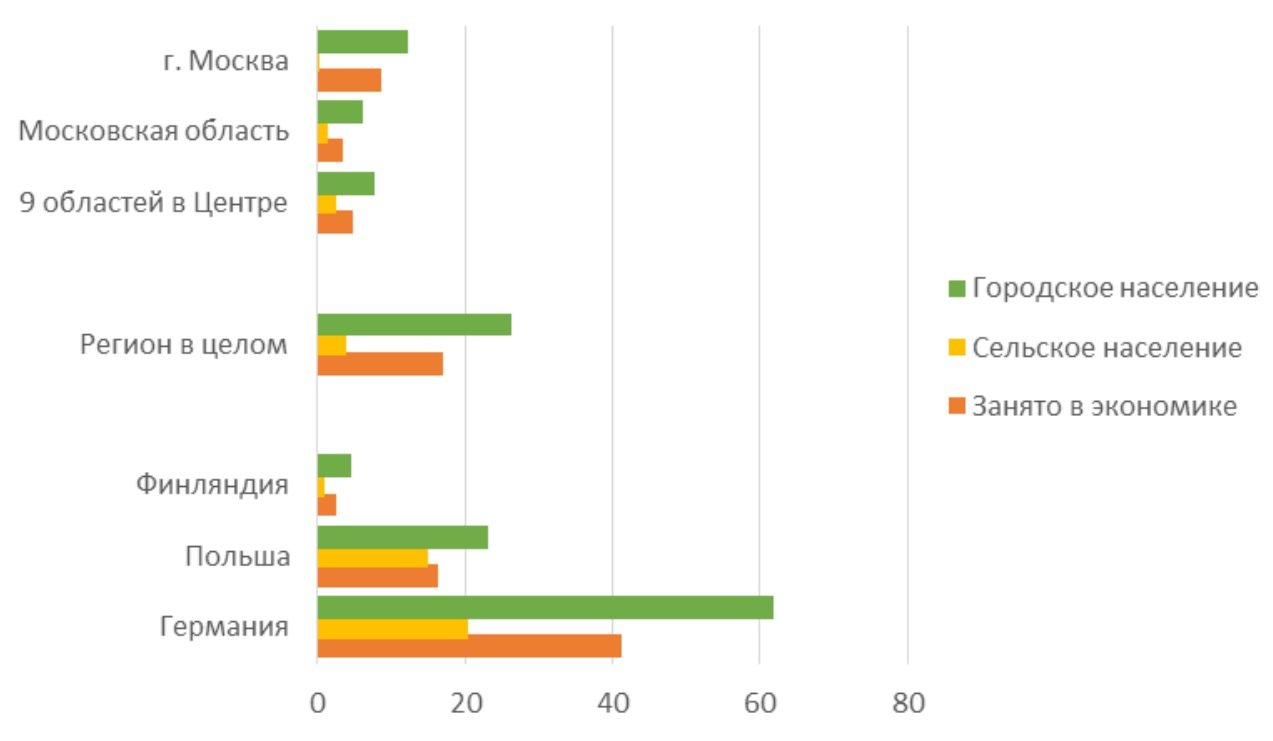

Рисунок 2. Численность городского, сельского населения и занятых в экономике нечерноземных (НЧ3) регионов в центре России и некоторых европейских странах, 2016, млн чел.

Источник: (Росстат 2018).

У нас это часть, староосвоенная еще 100 лет тому назад довольно плотно (рисунок 3). Тут отмечали избыток сельского населения, которому малоплодородных земель явно не хватало (Чаянов 1989), что выталкивало крестьян в города и вело к ранней урбанизации.

Её трактовка как серии стадий от концентрации населения в главных центрах до его рассредоточения по малым городам и весям (Gibbs 1963; Berry 1976; Fielding 1989) вылилась в схему дифференциальной урбанизации, когда стадии отличает динамика трёх категорий пунктов (Geyer, Kontuly 1993; Richardson 1980 и др.). Рисунок 4 показывает волнообразный ход процесса в России, прерываемый войнами и революциями. Возврат после срыва к новому старту с лидерством главных центров растянул урбанизацию на весь XX век. К его концу наметился плавный разворот, однако выход из кризиса

\footnotetext{
${ }^{3}$ Выбор обусловлен стремлением сосредоточиться на нечернозёмной части Центра (у чернозёмной условия и проблемы свои). Однако это не столь принципиально. Иногда используются данные по всему Центральному федеральному округу или другому кругу регионов в данной части страны.
} 
1990-х годов на фоне усиления экономической и политической централизации вновь активизировал рост крупнейших центров, прежде всего Москвы.

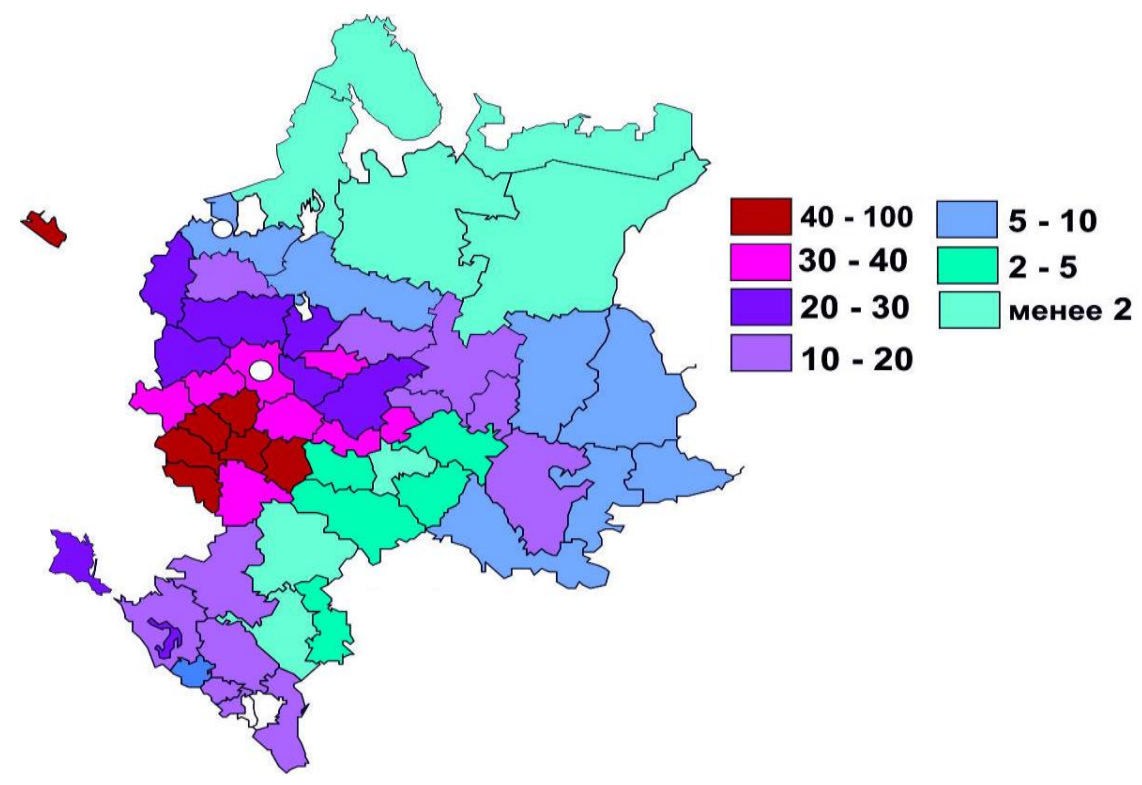

Рисунок 3. Плотность сельского населения в 1897 г. по регионам Европейской России современного состава, чел./км²

Источник: Расчеты авторов.

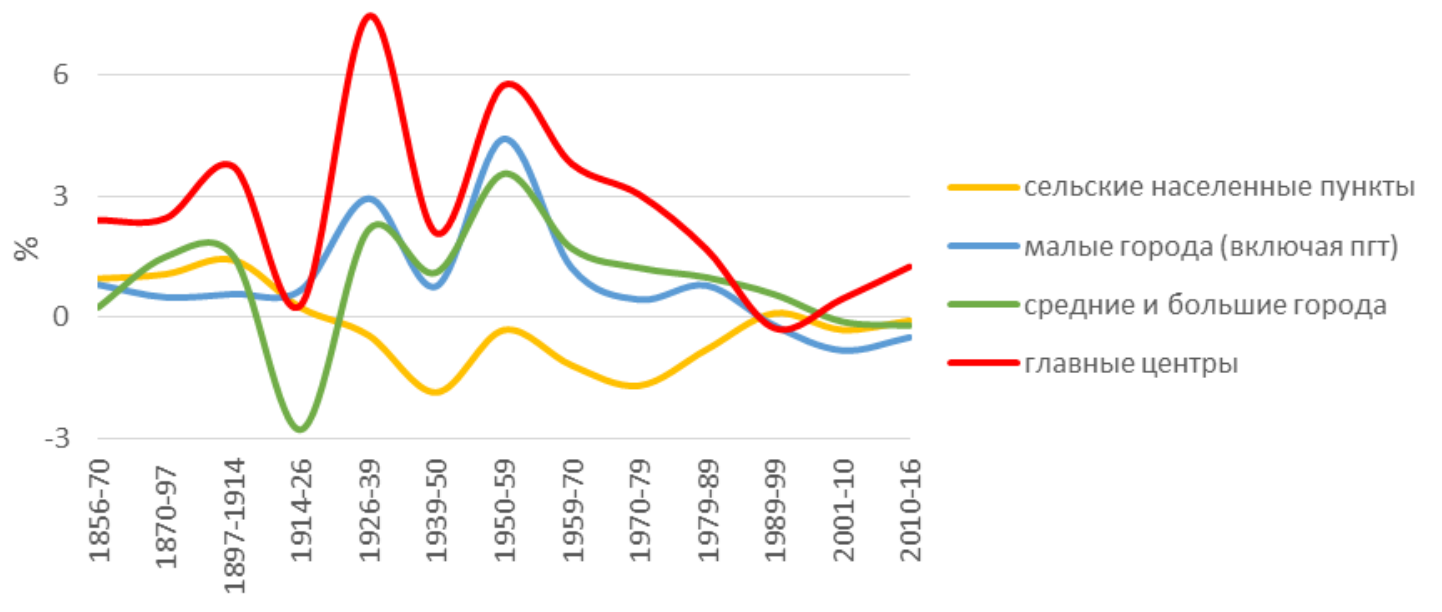

Рисунок 4. Волны урбанизации в России. Среднегодовые темпы динамики населения в городах разного размера и сельской местности, \% 4

Источник: (Нефедова, Трейвиш 2017).

\footnotetext{
${ }^{4}$ При построении графика в разные периоды применялись неодинаковые критерии главных, средних и малых поселений, т. е. шкала была скользящей для промежуточной категории, задающей также рамки главных и малых центров (в тыс. чел.): до 1897 г. - 5-20; в 1897-1926 гг. - 10-50; в 1926-59 гг. - 20-100; в 1960-х - 40-200; с 1970-х годах - 50-250. Население городов по возможности взято в границах на данный период, а не по ретроспективным расчетам с учётом позднейших расширений.
} 
Наибольшие контрасты между Москвой, Подмосковьем и окрестными регионами характерны для конца 1990-х гг. Начиная с 2000-х вокруг столицы начинается выборочное восстановление индустрии, сельского хозяйства, всего, что не помещается или слишком дорого обходится в Москве. Это сократило её отрыв от Подмосковья, а вот показатели окружающих областей всё так же отставали от МСР и общероссийского уровня (таблица), что стимулировало миграции в столичный регион.

Таблица. Сравнение избранных душевых показателей Москвы, регионов, смежных с МСР, и России в целом с показателями Московской области, принятыми за 1

\begin{tabular}{l|c|c|c|c|c|c|c|c|c}
\hline & \multicolumn{3}{|c|}{ Доходы населения } & \multicolumn{3}{c|}{ Валовой продукт } & \multicolumn{3}{c}{ Розничный товарооборот } \\
\cline { 2 - 12 } & 2001 & 2010 & 2017 & 2001 & 2010 & 2017 & 2001 & 2010 & 2017 \\
\hline Москва & 4,5 & 2,0 & 1,5 & 5,2 & 3,0 & 2,4 & 5,5 & 1,7 & 1,4 \\
Регионы вокруг МСР & 0,7 & 0,6 & 0,6 & 0,9 & 0,6 & 0,6 & 0,6 & 0,6 & 0,6 \\
РФ в целом & 1,2 & 0,8 & 0,8 & 1,4 & 1,0 & 1,0 & 1,1 & 0,8 & 0,7 \\
\hline
\end{tabular}

Источник: Расчет по данным Росстата.

За его пределами (в данном случае без южного сектора нашего ареала) динамика городов следовала тем же циклам с пиками в годы сталинской индустриализации и в 1960-е (рисунок 5). После кризиса 1990-х годов, захватившего здесь часть 2000-х, рост населения, но уже гораздо меньший, отмечался в центрах размером более 250 тыс. человек, что говорит о возврате к классической урбанизации, как во всей России, обусловленной, в первую очередь, миграцией населения.

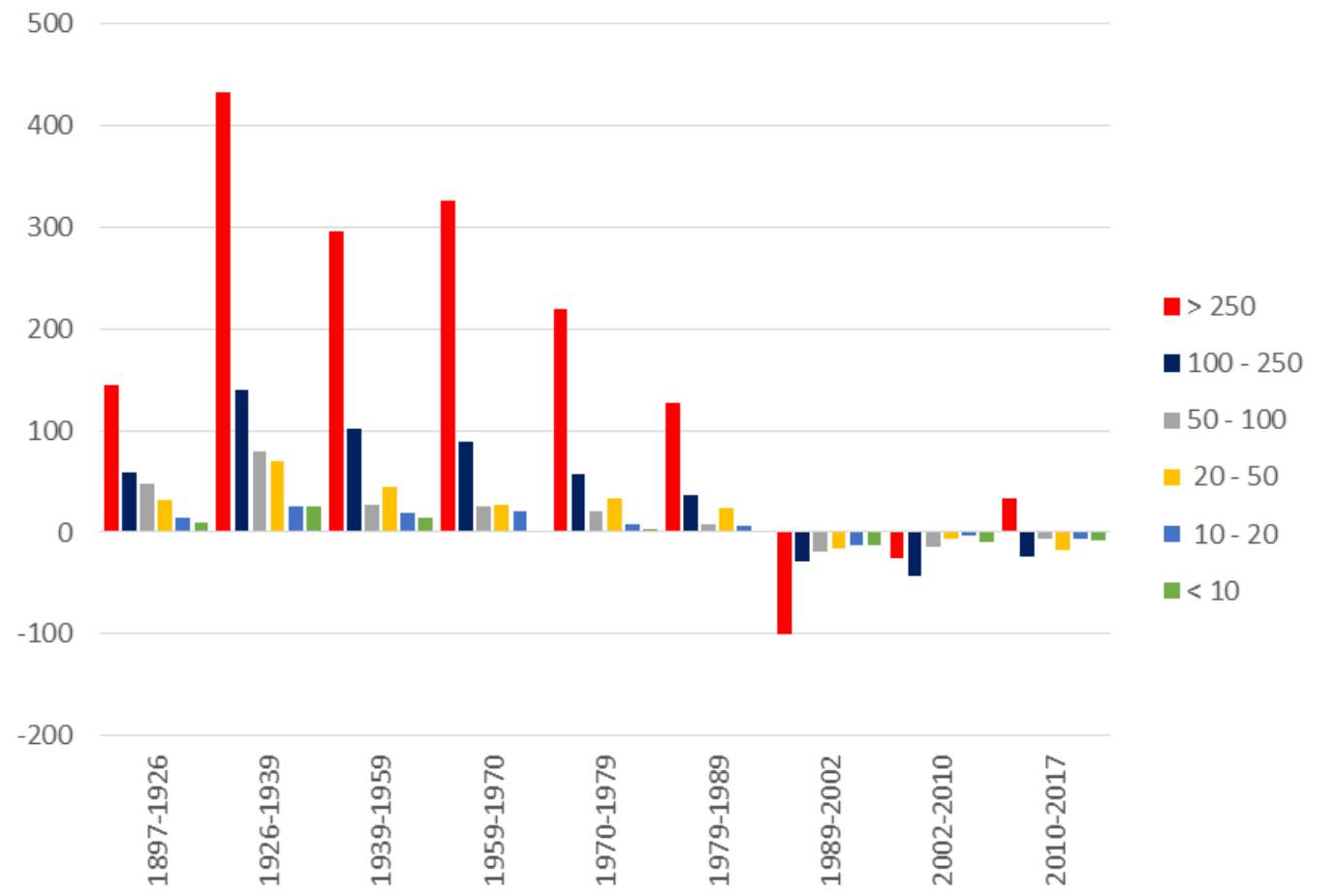

Рисунок 5. Прирост (убыль) населения городов разного размера в регионах, примыкающих к МСР с запада, севера и востока, тыс. чел.

Источник: Расчеты авторов по данным Росстата. 


\section{МИГРАЦИИ И ЗАНЯТОСТЬ КАК ИНДИКАТОРЫ РАССЛОЕНИЯ СОЦИАЛЬНО-ЭКОНОМИЧЕСКОГО ПРОСТРАНСТВА ВНУТРИ РЕГИОНОВ}

В большинстве областей Центра миграционный прирост отличает их центры и пригороды, т. е. агломерации (Мкртчян 2018; 2019). Так, в Ярославской области устойчивый положительный баланс в 2010-х годах имел один Ярославль, привлекавший всех мигрантов, особенно межрегиональных и международных. А пригородный Ярославский район стягивал население из малых городов и деревень области. Почти все малые города теряли жителей, притягивая мигрантов только из-за рубежа (рисунок 6). Прочие районы тоже привлекали почти исключительно таких мигрантов. И, что существенно, не все там укоренялись. Многие получили российское гражданство и постоянную регистрацию в сельской местности, где дешевле жильё, чтобы ездить оттуда на работу в МСР.

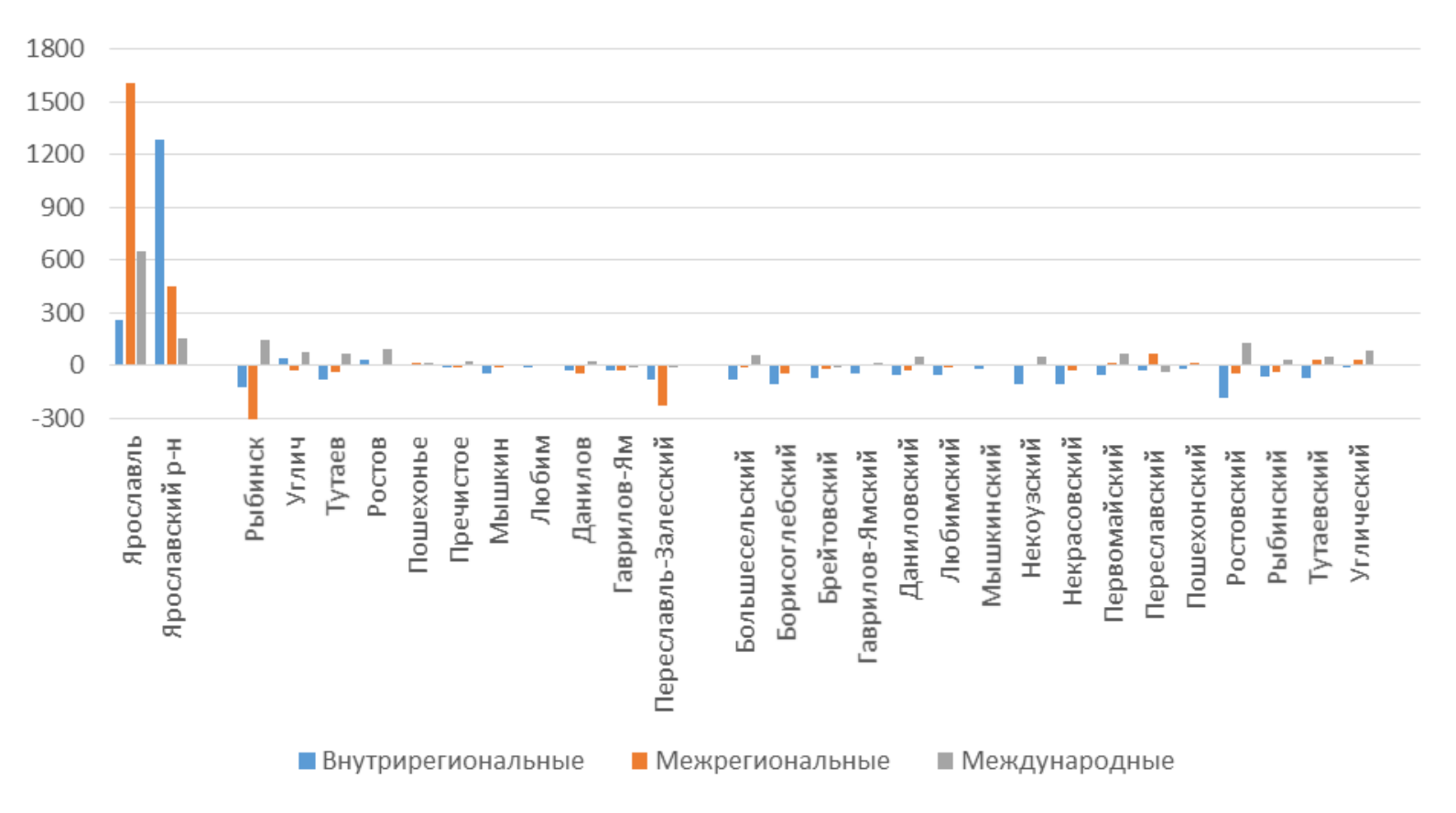

Рисунок 6. Среднегодовой баланс внутриобластных, межрегиональных и международных миграций в городах и районах Ярославской области за 2015-2017 гг., человек

Источник: Данные Росстата.

В ближайших пригородах Москвы по всему её нынешнему периметру ежегодно добавляется население, равное среднему городу, в основном за счет других регионов России (рисунок 7). Сальдо международных миграций здесь немногим больше 5 тыс. в год и столько же - у выходцев из более далёких районов Подмосковья. Муниципалитеты соседи Москвы второго порядка стягивали столько же мигрантов из-за рубежа, но намного меньше других. Все остальные районы теряли свое население и были гораздо менее привлекательными для нероссийских мигрантов. Эти цифры кажутся небольшими только в сравнении с ближайшим Подмосковьем. Так, суммарное сальдо международных миграций в 3-м и 4-м поясах равно таковому во всей Ярославской области. В ближайшую к Москве зону устремляется население как из регионов России, в том числе удаленных, так и из самой 
Москвы, фактически расширяемой многоэтажными кварталами за городской чертой, коттеджными и дачными массивами.

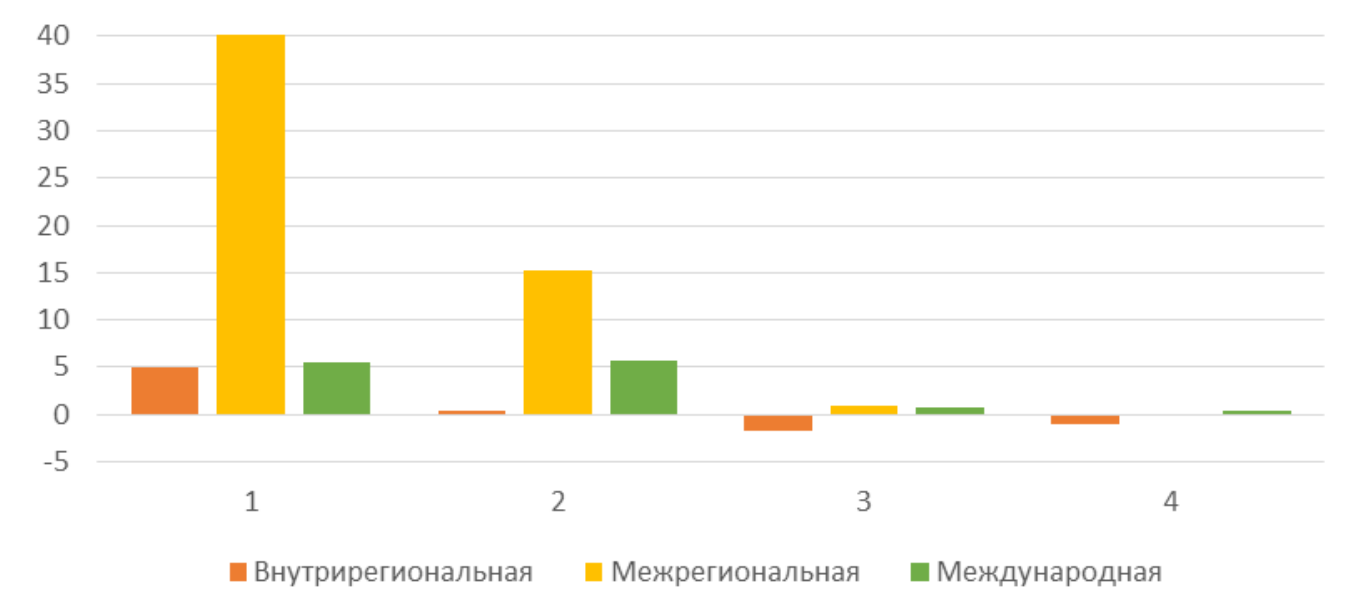

Рисунок 7. Баланс миграций в Московской области по поясам соседства муниципальных единиц с Москвой в среднем за 2015-2017 гг., тыс. чел./год

Источник: Данные Росстата.

Примечание: 1 - городские округа и мунищипальные районы, граничащие с Москвой, 2 - соседи второго порядка, 3 и 4 - соседи третьего и четвертого порядка.

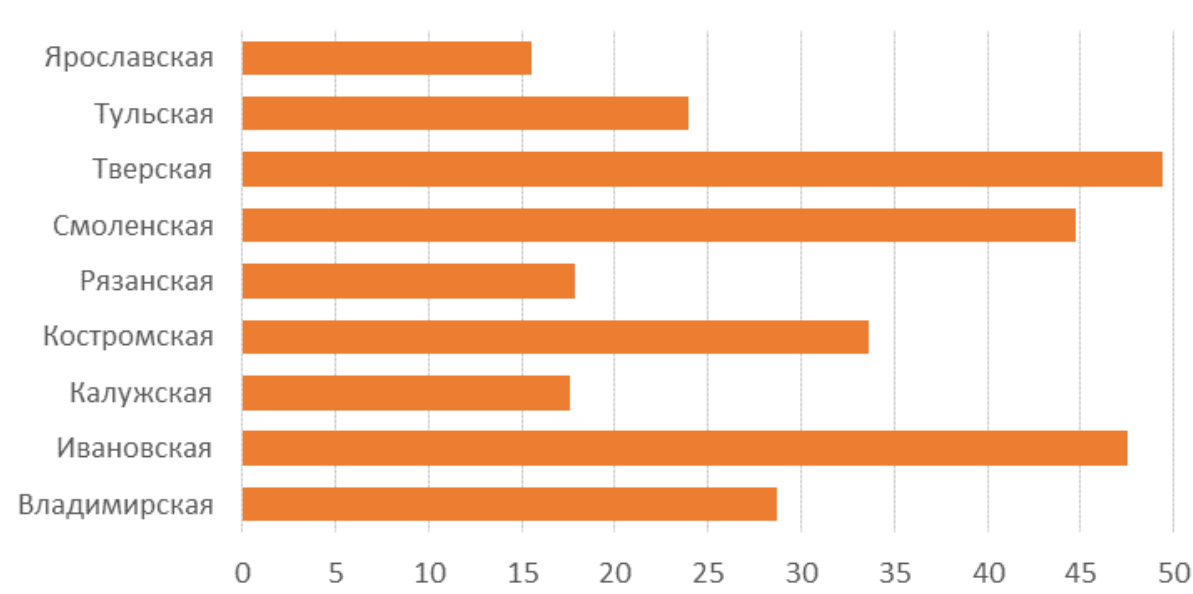

Рисунок 8. Доля населения в городах с пониженными оценками относительного благополучия, 2013, \% к городскому населению областей

Источник: Расчеты авторов по данным Росстата.

Миграции зависят от состояния городов. Такое состояние можно оценить набором показателей (доля незанятых в экономически активном населении, зарплата, душевые инвестиции и оборот розничной торговли и услуг, ввод жилья и его обеспеченность канализацией $)^{5}$. Высокие оценки в областях вокруг МСР имели региональные центры, а неблагополучных городов было больше всего в Тверской, Ивановской, Смоленской областях (рисунок 8). В этих городах, обычно малых и средних, живут около 3 млн чел.

${ }^{5}$ Но до 2013 г., так как Росстат перестал публиковать сводные базы данных по всем городам. 
И если пожилые смирились с упадком, то молодежь бежит оттуда в МСР либо в центр региона.

Населения, занятого в официальных организациях, частных и бюджетных, т. е. имеющего более или менее стабильную работу, в исследуемых регионах Центра меньше половины всего трудоспособного. Прочим остаются малый бизнес, жизнь на иждивении, огородах или поиск удаленной работы. Трудовой отход стал способом выживания для многих. Местами доля тех, кто ездит на заработки в другие регионы, достигает четверти трудоспособного сельского населения (Нефедова, Аверкиева, Махрова 2016).

Да и постоянная работа на месте не гарантирует достатка: оплата равного труда далеко не одинакова и тоже зависит от расстояния до главных центров. Контрасты между муниципальными районами, например в Тверской области и в столичных пригородах, велики и растут (рисунок 9). Повышен уровень зарплат и в пригороде Санкт-Петербурга, но не так заметно, как в МСР. Подобные кратные градиенты опять же приводят к трудовому отходу в столичные агломерации. Там больше шансов и на образование, а часто (хотя не всегда) и на профессиональный рост. Пространственная мобильность в этом случае - выход из отсутствия дома путей вертикальной социальной мобильности.

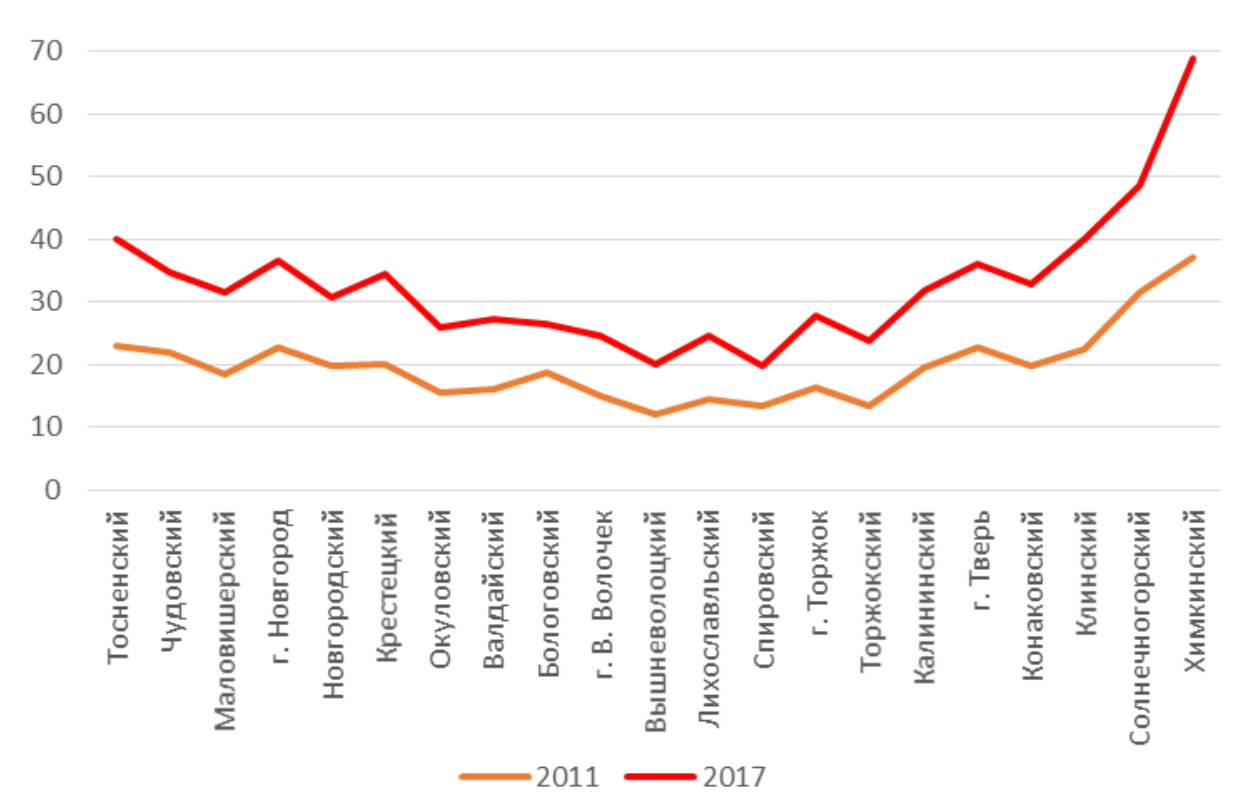

Рисунок 9. Средний уровень заработной платы в городских округах, городах и муниципальных районах по трассе Москва - Санкт-Петербург, 2011 и 2017, тыс. руб.

Источник: Данные Росстата.

Кроме размера и административного статуса города, на занятость населения влияет его экономический профиль. В лучшем положении малые города при атомных и других электростанциях (Удомля, Десногорск, Волгореченск и др.), известные туристические центры (Суздаль, Ростов). Но ещё важнее близость к МСР. Во Владимирской области выделяются Покров, Петушки, Александров, в Рязанской - Рыбное, Новомичуринск, в Смоленской - Гагарин, в Калужской - Обнинск, Жуков, Малоярославец. Власти этой области ещё в 2000-х годах, учтя выгоды положения рядом с ёмким рынком, развивали кластеры: автостроительный, биофармацевтический, стройматериалов, транспортно- 
логистический. После расширения столицы на юго-запад в 2012 г. Калуга оказалась в 80 км от Новой Москвы. Местности между ними стали территориями ускоренного развития. Промышленные зоны (Ворсино с электрометаллургическим заводом) созданы в чистом поле у порога Новой Москвой. Это не сняло проблемы поляризации пространства области. Её север с Калугой дают более 90\% промышленной продукции, концентрируя 82\% занятых на предприятиях и в организациях. А большинство из 16 малых городов с населением от 4 до 15 тыс. жителей испытывают тяжелую экономическую депрессию.

Анализ Д.Н. Мокренским (2019) демоэкономического развития муниципальных образований Центрального федерального округа показал, что депопуляции, как правило, сопутствуют старение и феминизация населения, общее ослабление демографического потенциала. Стандартная группировка муниципалитетов по направлениям естественного и механического движения выявила убыль за счёт того и другого в $72 \%$ случаев, естественную убыль с притоком мигрантов - в 26\%. И лишь по $1 \%$ составили единицы с положительной динамикой обоих слагаемых (чаще на чернозёмном юге, как в Белгороде и его районе) либо с естественным приростом при миграционном оттоке. Данные Мокренского подтвердили обратную связь миграционной динамики с дистанцией до центра региона или МСР. При прочих равных условиях потери заметнее в удаленных сельских ареалах.

\section{СЕЛЬСКАЯ ДЕПОПУЛЯЦИЯ И ЗЕМЛЕПОЛЬЗОВАНИЕ}

Сельская местность центральных районов России в XX веке пострадала особенно сильно. Урбанизация истощила сельское население и изменила сельскую среду. Здесь больше всего малых и заброшенных деревень (Alekseev, Safronov 2015; Нефедова 2018), низкая рождаемость, высокая смертность (рисунки 10, 11).

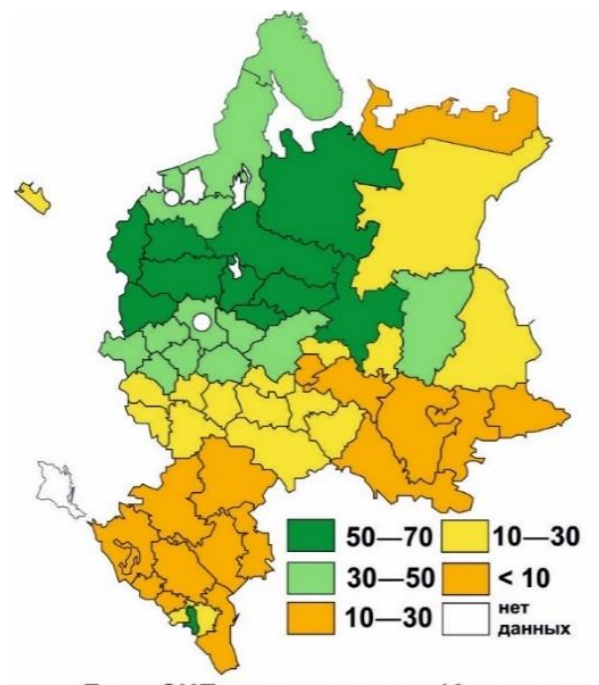

Рисунок 10. Доля мельчайших (до 10 чел.) и нежилых населенных пунктов, \%

Источник: Данные всероссийской переписи населения 2010 г.

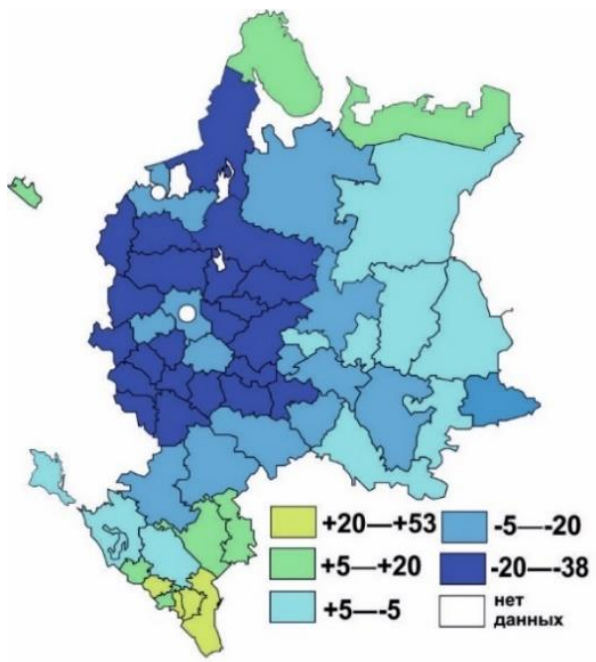

Рисунок 11. Естественный прирост в среднем за 2014-2016 гг., чел. /1000 жителей села

Источник: Данные Росстата. 
Это одно из самых «больных» в демографическом отношении мест страны, прежде всего за счёт глубинки (периферии регионов), в силу традиционного для России при её расстояниях между большими городами пригородно-периферийного расслоения сельской местности (Иоффе, Нефедова 2001). Динамика её жителей в постсоветские годы зависела от дистанции до центра региона: чем ближе к нему, тем потери меньше, совсем рядом их могло и не быть. Вдали от центров населения стало меньше наполовину (рисунок 12).

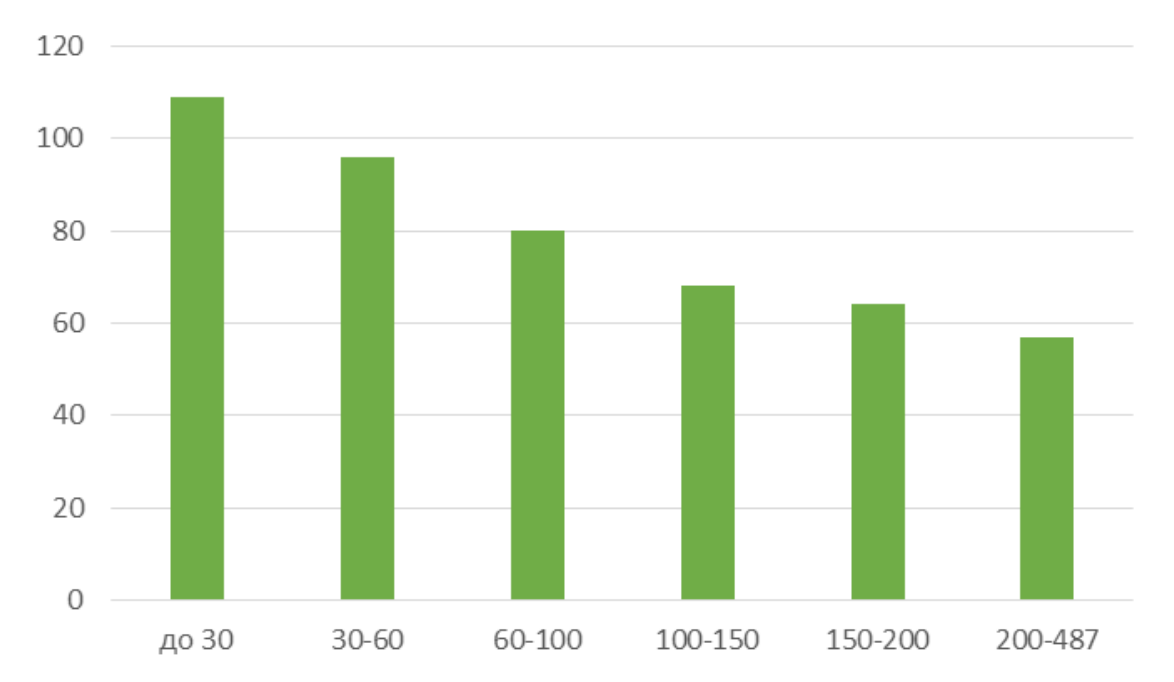

\section{Рисунок 12. Динамика сельского населения по зонам удаления от областных центров (км) в регионах Центральной России, 1991-2017, \%}

Источник: Данные Росстата.

Сжатию освоенных территорий способствовала убыль числа сельскохозяйственных предприятий и обрабатываемых ими земель. В 1990-х и в начале 2000-х годов пространственная картина поляризации агросектора мало отличалась от демографической: быстрее забрасывались периферийные земли, чем пригородные с их накопленным капиталом, включая человеческий, близостью к потребителю. Факторами забрасывания земель были также низкое качество нечернозёмных почв и мелкоконтурность угодий. Крупным животноводческим и птицеводческим предприятиям стало выгоднее выращивать корма в своих же подразделениях на Юге, где лучше природные условия и не так истощен трудовой потенциал.

В последние годы ситуация меняется. Современные малые и средние хозяйства (наследники колхозов), не говоря о мощных агрохолдингах, используют новые всё менее трудоёмкие технологии. При резком сокращении посевных площадей в 1990-х годах и незначительном возврате земель в оборот в южной части Центра в 2000-х объёмы производства молока и мяса восстанавливаются почти везде, но лишь за счёт отдельных очагов. Помимо пригородов, это так называемые ополья с менее кислыми дренированными почвами, где полеводство эффективнее. В Нечерноземной зоне оно выживает, таким образом, выборочно, там, где лучше природные предпосылки или вблизи городов, а освоенные и даже мелиорированные в советское время менее плодородные земли зарастают лесом. Вернуть их в оборот нелегко и вряд ли целесообразно. 
Местные власти ищут замену традиционным отраслям первичного сектора в виде развития туризма. Однако редкая сеть его самых привлекательных объектов при плохих дорогах делает повсеместность этой стратегии маловероятной.

Сокращение привычных рабочих мест дополняет упадок личных подсобных хозяйств, особенно животноводческих, в том числе из-за старения населения (Нефедова 2013: 15-148). Это делает их неустойчивыми. Слабая дорожная сеть, частое отсутствие сетевого газа и водопровода довершают картину неблагополучия сельской местности, усиленного «оптимизацией» бюджетной сферы. Во многих глубинных поселениях 60-90\% занятых работали в администрациях, школах, больницах, фельдшерских пунктах, клубах. Поэтому «оптимизация» больно ударила по ним, и не только по занятости, но и по доступности социальных услуг всему населению.

\section{ПРЕДВАРИТЕЛЬНЫЕ ВЫВОДЫ И ВОПРОСЫ ДЛЯ ОБСУЖДЕНИЯ}

Пора приподняться над фактами поляризации и сжатия пространства, демографического запустения значительной части центра России. Их анализ позволяет сделать выводы, из которых вытекают вопросы научно-практического характера. Ответы совсем не очевидны, в том числе для авторов статьи, поэтому ограничимся здесь их постановкой.

Вокруг Москвы работают обе стороны влияния крупного города на его окружение: a) выкачивание этим центром многих ресурсов с окружающих территорий и б) диффузия инноваций и стимулов развития к периферии. Первая пока явно преобладает. Почему так происходит - из-за всеохватной централизации власти, как её проекция в пространстве? Тогда каковы механизмы этого проецирования? Или у данного тренда есть ещё какие-то веские причины?

Экономическая поляризация пространства, определённо связанная со спецификой российских институтов, стимулирует миграции в главные центры и их пригороды, в свою очередь пролонгируя урбанизацию и экономическую поляризацию. Как разорвать этот круг? Может ли регион (и вся страна) развиваться иначе?

Централизм управления сочетается с ростом роли личных и групповых факторов развития на низовом уровне (ролью руководителей больших и малых предприятий, активистов, волонтёров). Как совместить разнонаправленные тренды регулирования всего и вся сверху и частично смягчающих, компенсирующих это давление инициатив снизу? Как не загубить ростки последних?

Историческое ядро России - территория с уникальным культурным наследием. Как сохранить его в условиях поляризации активного пространства, его сжатия к центру и социально-экономического опустынивания периферии? Ведь оно оборачивается разрухой, забрасыванием и зарастанием полей и деревень, старинных усадеб и отеческих гробов, многих памятников истории и культуры.

При невозможности вертикальной социальной мобильности она трансформируется в возвратную пространственную, трудовую и дачную (последняя иногда перерастает в центробежную безвозвратную, но вкупе с тем, что социологи называют дауншифтингом, 
особенно если человек близок к завершению карьеры, не видит её перспективы в центре). Обе помогают сохранять сеть расселения, очаговую освоенность и социальный контроль территории, не снимая экономических контрастов. Стоит ли поддержать эти процессы за то, что они сглаживают часть последствий поляризации, и если да, то как?

\section{ЧТО ЖЕ ДЕЛАТЬ?}

Попробуем выяснить, как можно или нужно отнестись к поляризации и сжатию в рамках обычного российского вопроса «Что делать?», вскользь затронув другой: «Кто виноват?». Надо ли что-то предпринимать вообще, да или нет и почему?

Негативное отношение к названным процессам есть на обоих полюсах. Теряющая население, земли, деньги периферия видит в них катастрофу опустынивания и забвения («нас бросили», «Москве не до нас») как потерю наследия в его самом широком смысле: демографическом, хозяйственном, культурном. Отсюда призывы в некоторых СМИ к «размосквичиванию» России, ведь страна куда больше и важнее столицы. Центрам тоже несладко, там сжатие воспринимается как перегрузка, переуплотнение (сколько может расти Москва?), как «понаехали тут» и др. В этой связи кому-то нравится другой лозунг («расстоличивания Москвы»), за которым скрыта надежда, что без столичных функций она перестанет «пухнуть». У экспертов и чиновников, в отличие от широкой публики, мнения бывают другие и самые разные.

Можно выделить четыре основных варианта оценки ситуации (а также сценария событий) и соответствующей политики.

Первый: не делать ничего. По-французски laissez-faire - пустить на самотёк, а жизнь разберётся, и, быть может, повернёт вспять. Мы ведь знаем, что урбанистические тела расширяются: город вырастает в агломерацию, а она - в более сложное образование типа мегалополиса. С другой стороны, при дефиците демографических ресурсов, росте доступности территорий и выравнивании условий жизни урбанизация рано или поздно затухает, переходя в свою противоположность - дезурбанизацию. Вот и подождём, пока то, другое или всё вместе не произойдёт само собой.

Проблема, во-первых, в том, что сеть центров у нас редкая. Для 100-тысячных и более крупных городов расчетное среднее расстояние ближайшего соседства превышает 300 км. Даже в Центральном федеральном округе - более 100 км. Без МСР (с 44\% городов округа) это 160 км. В ядре Евросоюза вдвое меньше: 80 км, от 45 в Нидерландах до 115 во Франции. Какая разница, 80 или 160? Немалая! Радиус рядовых агломерационных зон составляет от 25-30 до 50-60 км, в среднем примерно 40. Поэтому в зарубежной Европе они сомкнутся на прямой линии между городами-ядрами. В центре России половина пути в 160 км остаётся вне агломераций, очагов концентрации населения и развития, а люди в этих промежутках живут. Но как же США, Китай, другие обширные страны, где большие города разделяют не менее 100-150 км? Тут очень важен транспорт. Высокоскоростное наземное движение у нас есть между Москвой и Петербургом и мало где ещё; воздушное с 1990 г. тоже сжалось к столичному узлу (Тархов 2018). Так что первая причина разреженность городского социально-экономического пространства. Так, в Центральном 
районе вне МСР не хватает как минимум 10 больших городов, а в освоенной части всей Европейской России - 64 городов (Нефедова 2013 :300).

Вторая проблема - это централизация управления, о которой уже шла речь, а также особая роль административной и столичной ренты, следствия концентрации элит и выгод для бизнеса, политических, творческих и прочих карьер, даже для рядовой жизни, связанных с близостью к центрам принятия решений (Зубаревич 2012). Пока это так, в регионах будут расти в основном их центры, а в стране в целом - МСР.

Третья причина в том, что с некоторых пор Россия не совсем повторяет западные стадии урбанизации и может не дождаться её разворота. Массовая дезурбанизация наряду со стягиванием в города постоянных жителей у нас давно идёт в особом дачном виде или, как говорят западные коллеги, на базе второго дома (Roca 2013 и др.). Это связано с сезонностью климата, глубиной дачной традиции, теснотой городских квартир и широтой функций наших дач, включая чуждую западным странам подсобно-аграрную для самоснабжения, если продукты дефицитны или резко дорожают (Нефедова, Аверкиева, Махрова 2016). Дача - это и жилая, земельная недвижимость, т. е. собственность, отдых с близостью к природе, место для основных или альтернативных занятий (хобби) в иной среде, убежище от сует, ритмов и рисков мегаполиса ${ }^{6}$.

Россия - дачный чемпион мира в абсолютном и даже в относительном зачете, хотя доля дачников почти так же велика в постсоветских и Скандинавских странах. Многим же другим, в том числе крупнейшим, явление малознакомо или незнакомо совсем. У нас нет полной статистики всех дач, не только в садовых и дачных товариществах, коттеджных посёлках, но и покупных или наследных владений горожан в сельских и малых городских поселениях. По оценкам, дачей того или иного типа обладают не менее 50\% городских семей. Однако наша страна, увы, не лидер мирового «дачеведения» (Трейвиш 2014).

Второй вариант, ещё более радикальный в отношении слабеющей периферии, ускорение сжсатия хотя бы ради экономии бюджетных средств. Разновидность этой линии - ставка на развитие только крупных агломераций, ведь периферия-то безнадежна и никому не нужна. С трибун так не говорят, но в кабинетах могут думать, и это роднит их обитателей с «зелёными» экстремистами. Пусть уж лучше туда вернётся дикая природа, создадим особо охраняемые территории, они усилят позиции России как великой экологической державы, донора всея планеты. Хотя этот актив слабо капитализирован, экономически малозначим, что-то меняется (начиная с Киотского протокола), и дело, видимо, идет к тому, что на природном капитале и экоуслугах можно будет зарабатывать.

На практике в последние годы, по сути, реализуется этот вариант или что-то к нему близкое. Укрупняются сельские поселения, да и городские тоже, что ведёт к ликвидации части социальной инфраструктуры: малых школ, больниц, клубов. Более того, к северу от МСР, где много леса, местное начальство порой действует так, будто населения вообще не осталось. Конечно, чиновник заботится о нём по долгу службы, но тысяч на 25 зарплаты даже главе типового сельского поселения с семьёй не прожить, и он подрабатывает лесом

\footnotetext{
6 Что наглядно подтверждают многочисленные факты самоизоляции городских семей именно на дачах в период пандемии COVID-19, т. е. как раз в дни, когда пишутся эти строки.
} 
и промыслами: организует лесозаготовки, элитную охоту, рыбалку и др. Много людей для этого не требуется.

Конечно, этот сценарий встречает критику, и оппоненты говорят: ненужных земель у страны нет и быть не может. Мы просто не знаем, когда и кому они понадобятся. Это же не просто территории, а носители культуры и традиций, когда-то, между прочим, бывшие новациями, прославившими города, районы, всю страну. Миллионы там пока что живут, и лучше их удерживать, потому что руины и пустыри без социального контроля дичают, притом дичают опасно, особенно рядом с ещё обитаемым жильём. Они надолго остаются уже не культурными элементами ландшафта и ещё не природными, приютом маргиналов, бомжей (и людей, и зверья), уродливы и легко горят. Скорее это ландшафты пустырные или мусорные.

Третий вариант: раз такое запустение нехорошо, надо его тормозить, как-то сдерживать, смягчать его издержки, а не «бежать впереди паровоза». Инструменты для этого, в общем, есть. Они могут быть затратными, как введение периферийных льгот и надбавок по типу северных, придуманных в СССР, чтобы население ехало на Север и там оставалось. Так давайте введём периферийные льготы, потому что в глубинке жить тоже тяжело, а надо, чтобы там кто-то жил. Ведь всего в 100-150 км от Москвы можно найти участки настоящей глухомани. Но это немалые деньги.

Есть экономные средства. Вот частный пример решения школьной проблемы. В поселении (а это давно целая группа сёл и деревень) укрупнили школу, оставив из двух одну. Ходит школьный автобус, даже укладываясь в расписание и будучи в таких краях главным средством общественного транспорта. Сначала идёт километров за 20 в дальнюю деревню, где была школа, и в соседнюю, где не было. Там по два ученика в каждой и 3 км дистанции. Потом - во все другие пункты, чтобы привезти детей в начальную школу центрального посёлка. И что это значит для 7-летнего карапуза? До 60 км, 2-2,5 часа в день по проселкам с остановками, ожиданием. Транспортная усталость и для взрослого. А в деревне, где была школа, живут учителя на пенсии, готовые за минимальную прибавку к ней научить детей читать, писать и считать не хуже, а то и лучше, чем школа. Пешком до ближней деревни - и то ближе, чем автобусом до центральной. С машиной, мотоциклом у родителя - считанные минуты. Такое применяется местами, например в Татарстане, но в большинстве регионов - нет . Проверять же знания можно в школе, как при экстернате.

Четвертый вариант: искать и поддерживать любую возвратную волну. Вряд ли дальние сельские районы Нечерноземья станут заметными очагами роста экономики. Но есть явление, не позволяющее списать их со счетов и доказывающее наличие спроса на них, - дачное освоение, своего рода реконкиста пустеющей глубинки горожанами (Нефедова, Аверкиева, Махрова 2016). Не повторяя былых аграрных и промышленных волн, эта зато достигает мест, пока действительно мало кому интересных, кроме дачников. Здесь важно, что дачи, при обилии их типов, местоположений и цен на них, доступны разным слоям россиян. Тут тоже не нужны особые затраты государства: люди их несут сами, а дорожную и другую инфраструктуру вообще-то надо развивать и так, с дачниками или без них. У дачного бума, как любого, есть теневые стороны, о которых нужно говорить отдельно, но это не повод его замалчивать. Между тем его фактически игнорируют 
стратегии и программы развития разного уровня, особенно федерального, да и регионального. В них много пишут о туризме, а о дачах, как правило, ничего. К ним вообще отношение лёгкое. Второй дом - он же не первый, что-то необязательное, подсобное. О даче пишут и снимают в шуточном или детективном жанре; действие посолиднее перенесут в иное место.

Официальная статистика имеется лишь по садовым и дачным посёлкам, в основном локализованным у городов и вдоль магистралей. Данных о покупных и наследных дачах на базе бывшего основного жилья нет, как и сведений о реальном населении в той или иной местности по сезонам года, дням недели. Появление таких владений в глубинке связано с урбанизацией: дома и участки наследовались, а затем использовались как дачи и продавались потомственным горожанам. Скупка ими сельских домов в дальних районах началась с 1970-х - 1980-х годов, когда она была еще неофициальной (собственность приходилось регистрировать на подставных лиц из местных). В 1990-2000-х годах на фоне уплотнения пригородов дальние дачи становятся популярными, особенно у москвичей и петербуржцев (Аверкиева, Нефедова 2016).

Такие дачники, в отличие от пригородных, ищут уединения на природе, иногда культурной экзотики. При опросах главными аттракторами они называют лес, реку или озеро, простор, тишину и, шире, экологию. Ради них они готовы мириться с бытовыми неудобствами, но совсем дикая природа, недоступность и отсутствие местного населения их отталкивают. А привлекают небольшие, но ещё живые деревни, пустеющие сельские ландшафты (что не препятствует формированию преимущественно дачных по составу летнего населения пунктов). Уровень заброшенности сельскохозяйственных земель и сеть малых деревень позволяют поэтому в отсутствие официальной статистики представить, куда направлены волны такого дачного освоения.

Зоны распространения дальних дач, чаще всего москвичей и петербуржцев, хотя и отодвинуты от пригородов, обычно ограничены радиусом 300-400 км от центров и еще не полностью опустевшими ареалами. Километры даже не так важны, как транспортная доступность. При наличии железной дороги, автотрассы и хоть сколько-то проезжего отрезка до места (у многих своя машина) дачники покупают сельские дома и на удалении до 600-700 км.

Летом в дальних деревнях, где зимуют менее 10 человек, число горожан может превышать их число пятикратно, если не более, при 10-50 постоянных жителей дачники могут составить половину их числа, а порой и столько же (Нефедова, Аверкиева, Махрова 2016). Но из пунктов, где местных жителей уже нет, обычно уходят и дачники ввиду выхода из строя дорог, отрезания электросетей и разграбления домов зимой, когда до них легче добраться на тракторе, грузовике.

Дачники сохраняют не только отдельные пункты, но и ту мелкоселенную систему, которую местное население с его демографией поддержать уже не в силах. Вот почему попытки властей «оптимизировать» локальную инфраструктуру, исходя из размеров постоянного населения без учета временного дачного, могут приводить к отказу горожан вкладывать деньги в сельскую недвижимость, а заодно усилить отток местных жителей. Для них дачи и дачники - довольно важный источник работы и дохода, от продажи даров 
огорода и леса, охраны домов до их ремонта и строительства, обустройства участков. Иначе говоря, такая политика по варианту 2, как уже упоминалось, существенно ускоряет социальное опустынивание глубинки.

Дачная волна вдали от центров не так устойчива, как в зонах лучшей доступности. Она требует союза с местным населением, длительного пребывания (на каждый уикенд не съездишь), более доступного старикам-пенсионерам с их малолетними внуками, а также лицам «свободных профессий». Сами дачи на базе старых деревенских домов и участков там весьма велики, но очень дёшевы по меркам пригородов. Это облегчает расставание с ними при случае если не первых, то следующих за ними поколений владельцев. Вместе с тем социальная среда таких дачных мест отличается сравнительной теснотой и теплотой соседских связей, а соседями часто считают дачников из деревень, разделённых большим расстоянием (до 10-20 км и более). Дачное отшельничество органически дополняет и компенсирует тяга к общению с себе подобными.

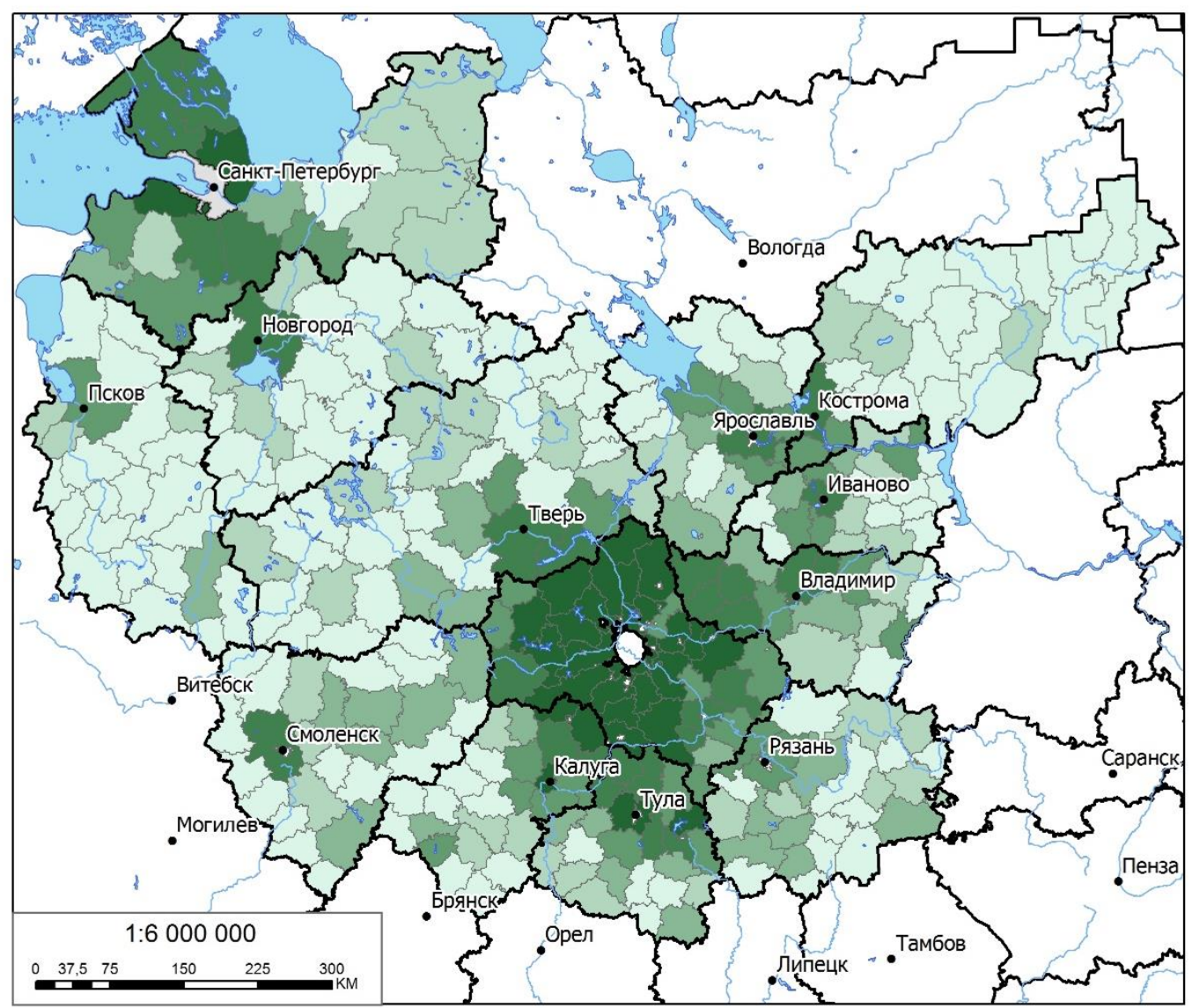

Число домохозяйств вне населенных пунктов на 100 кв. км менее $30 \square 30-100$ $100-200$ $200-500$ $500-1000$ более 1000

Рисунок 13. Плотность участков (домохозяйств) в садовых товариществах и коттеджных поселках, расположенных вне населенных пунктов, по муниципальным районам областей центрального и северо-западного Нечерноземья

Источник: (Махрова, Медведев, Нефедова 2016).

Примечание: Составлено по материалам дешифрирования космических снимков. 
Садовые товарищества жителей центров вроде Москвы и подмосковных городов тоже переросли рамки пригородов, сформировав особую, полностью не учитываемую ни статистикой, ни властями сеть расселения (рисунок 13). Некоторые и даже многие горожане остаются на дачах зимой. Но их учитывают совсем плохо, а вернее не учитывают, поскольку в большинстве случаев они зарегистрированы в центре. Между тем плотность горожандачников в сельской местности на расстояния до 140 км от Москвы уже превышает плотность сельского населения.

Именно эта дачная традиция, жизнь на два дома тормозит у нас субурбанизацию и дезурбанизацию западного образца, затягивая видимую урбанизацию и скрывая невидимый контрпроцесс. Поэтому важной задачей становится выявление территорий возможной экспансии горожан на дачи с учётом природных ландшафтов, транспортной доступности, наличия свободного жилого фонда, сохранности хотя бы современной социальной и дорожной инфраструктуры.

Там, где есть население и спрос, появляется бизнес, в том числе малый: торговля и услуги, строительство и ремонт. За ними приходят крупные сети. Вместе с очагами модернизированного сельского хозяйства, включая филиалы пригородных агрохолдингов, с энтузиастами-фермерами, лесными промыслами все это - новая постсоветская экономика. Она способствует и развитию туризма, особенно в местах с богатым культурным наследием, часто в виде инициатив местных жителей и горожан-дачников по созданию музеев, оформлению достопримечательных мест, организации экскурсий по памятным местам и др. Они могут удержать часть среднего и молодого поколения и привлечь горожан на более длительное проживание. А надолго ли - во многом зависит от политики федеральных и региональных властей.

\section{ЗАКЛЮЧЕНИЕ}

Итак, при всей важности северных и восточных, южных и западных окраин России самой вездесущей и социально значимой (затрагивающей больше всего людей) проблемой её пространственного развития остаётся центро-периферийная. Она остра всюду, в том числе в ядре страны, где перепад освоенности на малой дистанции бывает головокружительным. Его видят все, кто следует из Москвы, особенно на север и запад, поездом, автомобилем, при ясной погоде и самолётом: быстро редеют пятна застроенных и обрабатываемых земель, всё гуще массивы лесов, болот, пустошей на месте бывших полей. Свои центры и периферия есть в каждом регионе, муниципальном районе и даже в городском округе или сельском поселении. Из всех территориальных контрастов этот самый полимасштабный и повсеместный.

Как мы пытались показать, поляризация и сжатие пространства неприятны для обеих сторон, центральной и периферийной, но для второй всё же болезненнее. Однако устойчивость нашей внутренней периферии выше, чем может показаться. В 1990-е годы некоторые из наших коллег сулили ей скорый конец: если не в 2000 г., то в 2010 г. там (как раз в центре России) останется от силы треть поселений и обитаемых земель. Но к 2019 г. потери сельского населения составили 20\%, посевных площадей - 57\%, 
а районы с плотностью населения до 10 чел./км² заняли около 40\% ареала, выбранного для анализа в этой статье. Значит, что-то сдерживает сжатие и среди сдерживающих сил выделяется не ежедневная, но регулярно-возвратная мобильность населения в пространстве, трудовая и дачная. В обоих случаях это два дома, один из которых находится вне крупного центра. Оба связаны с определёнными издержками, но помогают людям (семьям) жить-выживать. Крайнее неудобство они доставляют разве что властям, теряющим ясное представление о подопечном, подконтрольном населении.

Тем не менее действия властей разного уровня влияют на динамику и состояние обсуждаемой проблемы. Сам выбор той или иной политики, тех или иных решений - их прерогатива. Мы, исследователи, могли только выделить четыре варианта, изложенных выше, с показом их плюсов и минусов. Единой позиции по ним, как по многим другим жгучим вопросам, нет ни у широкой публики, ни у экспертного сообщества. Что же касается нашего авторского отношения к вариантам, то меньше всего нам импонирует второй, реализуемый де-факто, а больше нравятся третий или четвёртый, хотя понятно, что последний пока имеет мало шансов на одобрение и осуществление.

\section{ЛИТЕРАТУРА}

Аверкиева К.В., Нефедова Т.Г. (2016). Дачная «колонизация» российской глубинки. Пример Костромской области. Мир России: соџиология, этнология, 1, 103-128.

Зубаревич Н.В. (2012). Рента столичного статуса. Pro et Contra. Москва как физическое и социальное пространство, 6(57), 6-18.

Иоффе Г.В., Нефедова Т.Г. (2001). Центр и периферия в сельском хозяйстве российских регионов. Проблемы прогнозирования, 6, 100-110.

Махрова А.Г., Медведев А.А., Нефедова Т.Г. (2016). Садово-дачные поселки горожан в системе сельского расселения. Вестник Моск. ун-та. Сер. 5. География, 2, 64-74.

Мкртчян Н.В. (2018). Региональные столицы России и их пригороды: особенности миграционного баланса. Известия РАН. Сер. геогр., 6, 26-38.

Мкртчян Н.В. (2019). Миграции в сельской местности России: территориальные различия. Население и экономика, 1(3), 39-52. URL: 10.3897/popecon.3.e34780.

Мокренский Д.Н. (2019). Экономико-демографическое развитие регионов России (на примере регионов Центрального Федерального округа). (Автореф. дисс. канд. экон. наук). М.: МГУ им. М.В. Ломоносова.

Нефедова Т.Г. (2013). Десять актуальных вопросов о сельской России: ответы географа (доп. изд-е 2017). М.: URSS-ЛЕНАНД.

Нефедова Т.Г. (2018). Факторы и тенденции изменения сельского расселения в России. Социально-экономическая география. Вестник Ассочиащии российских географовобществоведов (АРГО), 7, 4-21.

Нефедова Т.Г., Аверкиева К.В., Махрова А.Г. (Ред.) (2016). Между домом и... домом: возвратная пространственная мобильность населения России. М.: Новый Хронограф. URL: http://ekonom.igras.ru/data/bhah2016.pdf

Нефедова Т.Г., Трейвиш А.И. (2017). Перестройка расселения в современной России: урбанизация или дезурбанизация? Региональные исследования, 2 (56), 12-23. 
Росстат (2018). Россия и страны мира. Статистический сборник. М.

Тархов С.А. (2018). Изменения авиатранспортной связности городов России в 19902015 гг. Известия РАН, сер. Геогр., 4, 5-26.

Трейвиш А.И. (2010). «Сжатие» пространства: трактовки и модели. Сжатие социальноэкономического пространства: новое в теории регионального развития и практике его государственного регулирования. М.: ИГ РАН, МАРС, 16-32.

Трейвиш А.И. (2014). «Дачеведение» как наука о втором доме на Западе и в России. Известия РАН, сер. Геогр., 4, 22-32.

Хаггет П. (1979). География: синтез современных знаний. Пер. с англ. М.: Прогресс.

Чаянов А.В. (1989). Крестьянское хозяйство. М.: Экономика.

Alekseev A.I., Safronov S.G. (2015). Transformation trends of Russia's rural settlement patterns in the late soviet and post-soviet periods (1970-2010). Regional Research of Russia, 2(5), 193-201.

Berry B. (1976). The counterurbanization process: urban America since 1970. Urban Affairs Annual Reviews, 11, 17-31.

Fielding A. (1989). Migration and counterurbanization in Western Europe since 1950. Geographical Journal, 155, 60-69.

Geyer Y.S., Kontuly T. (1993). A Theoretical Foundation for the Concept of Differential Urbanization. International Regional Science Review, 15(2), 157-177.

Gibbs J. The evolution of population concentration (1963). Economic Geography, 2, 119-129.

Okun A.M. (1975). Equality and Efficiency: The Big Tradeoff. Washington, D.C.: Brookings Institution.

Richardson H.W. (1980). Polarization reversal in developing countries. Papers of the Regional Science Association, 45, 67-85.

Roca Z. (Ed.) (2013). Second Home Tourism in Europe: Lifestyle Issues and Policy Responses. Farnham, UK - Berlington, USA: Ashgate Publishing.

Rogers E.M. (1962). Diffusion of innovations. New York: Free Press of Glencoe. 


\title{
POLARIZATION AND SHRINKAGE OF ACTIVE SPACE IN THE CORE OF RUSSIA: TRENDS, PROBLEMS AND POSSIBLE SOLUTIONS
}

\section{TATYANA NEFEDOVA, ANDREY TREYVISH}

\begin{abstract}
The polarization and shrinkage of inhabited and economically active areas as a result of their extremely uneven development has become one of the key problems for not only the whole of Russia and its macroregions, but also for individual regions and groups of them. A study of one group, located in the country's historical core around Moscow, reveals sharp and growing contrasts of the center-periphery type, which are, generally speaking, particularly common in Russia. Factors behind this have been the specifics of crisisprone urbanization, centripetal migration, and depopulation of inner peripheries, particularly rural ones, under the post-Soviet spatial restructuring of the economy and settlement pattern. These processes are painful for both poles, the central as well as the peripheral, but the latter experiences more acute related problems and feels them more sharply. Their public, expert and official perceptions are different. The paper identifies four possible basic approaches to these problems, along with possible policies and solutions, such as (1) non-interference in the spirit of laissez-faire with the hopes of a natural change (reversal) of the shrinking trend; (2) acceleration of the trend in order to save budget funds by enlarging settlements and social facilities; (3) containment and mitigation of the trend's negative social consequences by affordable measures; and (4) the search and multi-faceted support for new, reverse waves of development (a kind of reconquest) of the empty periphery, among which the country (dachas) wave stands out as one of the most realistic, massive and, moreover, least costly for the state. Each option has its pluses and minuses, strengths and weaknesses, a quick review of which is contained in the article. But the choice of this or that path remains, as usual, up to politicians and managers.
\end{abstract}

Key words: space, center, periphery, (spatial) development, polarization, shrinkage, urbanization, depopulation, spatial population mobility, dacha (second home).

TAtyana Nefyodova (trene12@igras.ru), Institute of GEOGRAPHy, Russian ACAdEMy Of SciEnCES, Russia.

ANDREy Treyvish (trene12@yandex.ru), Institute of GEOGRAPHy, Russian ACADEMY of SCIENCEs, Russia.

THE WORK WAS SUPPORTED BY THE GRANT OF RUSSIAN SCIENCE FOUNDATION №19-17-00174 «EARLY DEVELOPED REGIONS UNDER SOCIO-ECONOMIC POLARIZATION AND SHRINKAGE OF ACTIVE SPACE IN EUROPEAN RUSSIA» IN THE INSTITUTE OF GEOGRAPHY, RAS

DATE RECEIVED: MARCH 2020.

\section{REFERENCES}

Alekseev A.I., Safronov S.G. (2015). Transformation trends of Russia's rural settlement patterns in the late soviet and post-soviet periods (1970-2010). Regional Research of Russia, 2(5), 193-201.

Averkieva K., Nefedova T. (2016). Dachas and the Colonization of Rural Areas by Urban Citizens in Russia: The Case of the Kostroma Region. Mir Rossii: sotsiologiya, etnologiya, 25 (1), 103-128. (In Russ.).

Berry B. (1976). The counterurbanization process: urban America since 1970. Urban Affairs Annual Reviews, 11, 17-31.

Chayanov A.V. (1989). Peasant economy. Moscow: Ekonomika. (In Russ.). 
Fielding A. (1989). Migration and counterurbanization in Western Europe since 1950. Geographical Journal, 155, 60-69.

Geyer Y.S., Kontuly T. (1993). A Theoretical Foundation for the Concept of Differential Urbanization. International Regional Science Review, 15(2), 157-177.

Gibbs J. The evolution of population concentration (1963). Economic Geography, 2, 119-129.

Haggett P. (1979). Geography: A Modern Synthesis. Moscow: Progress. (In Russ.).

Ioffe G.V., Nefedova T.G. (2001). The center and periphery in agriculture of Russia's regions. Journal for Economic Forecasting, 6, 100-110. (In Russ.).

Makhrova A.G., Medvedev A.A., Nefedova T.G. (2016). Garden and dacha settlements of urban dwellers in rural settlement system. Vestnik Moskovskogo Unviersiteta, Seriya Geografiya, 2, 64-74. (In Russ.).

Mkrtchyan N.V. (2018). Regional'nyye stolitsy Rossii i ikh prigorody: osobennosti migratsionnogo balansa [Regional capitals of Russia and their suburbs: features of the migration balance]. Izvestiya RAS, geographical series, 6, 26-38.

Mkrtchyan N.V. (2019). Migration in rural areas of Russia: territorial differences. Population and Economics, 1 (3), 39-52. URL: https://populationandeconomics.pensoft.net/article/34780/

Mokrensky D.N. (2019). Economic-demographic development of Russia's regions (an example of the regions of Central Federal district). (PhD Thesis). Moscow: Lomonosov State Unuversity. (In Russ.).

Nefedova T.G. (2013). Ten topical issues about rural Russia: A geographer's viewpoint (add. ed. 2017). Moscow: URSS-LENAND. (In Russ.).

Nefedova T.G. (2018). Factors and tendencies of rural settlement change in Russia. Socioeconomic geography. Bulletin of the Association of Russian social geographers (ARGO), 7, 4-21. (In Russ.).

Nefedova T.G., Averkieva K.V., A.G. Makhrova (Eds.) (2016). Between home and... home. The return spatial mobility of population in Russia. Moscow: Novyy KHronograf. (In Russ.). URL: http://ekonom.igras.ru/data/bhah2016.pdf

Nefedova T.G., Treyvish A.I. (2017). The transformation of settlement in modern Russia: urbanization or de-urbanization? Regional Studies, 2 (56), 12-23. (In Russ.).

Okun A.M. (1975). Equality and Efficiency: The Big Tradeoff. Washington, D.C.: Brookings Institution.

Richardson H.W. (1980). Polarization reversal in developing countries. Papers of the Regional Science Association, 45, 67-85.

Roca Z. (Ed.) (2013). Second Home Tourism in Europe: Lifestyle Issues and Policy Responses. Farnham, UK - Berlington, USA: Ashgate Publishing.

Rogers E.M. (1962). Diffusion of innovations. New York: Free Press of Glencoe.

Rosstat (2018). Russia and world countries. Statistical collection. Moscow. (In Russ.).

Tarkhov S.A. (2018). Changes in air transport connectivity of Russian cities in 1990-2015. Izvestiya RAS, geographical series, 4, 5-26. (In Russ.).

Treivish A.I. (2010). «Shrinking» space: interpretations and models. Shrinkage of socioeconomic space: New in the theory of regional development and practice of its state 
regulation. Moscow: Institute of geography RAS, International Academy for regional development and co-operation, 16-32. (In Russ.).

Treivish A.I. (2014). «Dacha studies» as the science on second homes in the West and in Russia. Izvestiya RAS, geographical series, 4, 22-32. (In Russ.).

Zubarevich N.V. (2012). The rent of capital city status. Pro et Contra. Moscow as a physical and social space, 6 (57), 6-18. (In Russ.). 